\title{
PENGERTIAN PATEN SERTA CARA PENYELESAIAN HAKI MENGENAI HAK PATEN
}

\section{Doni Winata \\ 165100085}

Fakultas Komputer, 4487571-83

doniwinata.student@umitra.ac.id

\begin{abstract}
Paten merupakan hak eksklusif yang diberikan oleh negara kepada inventor atas hasil invensinya di bidang teknologi untuk selama waktu tertentu melaksanakan sendiri invensinya atau memberikan persetujuan kepada pihak lain untuk melaksanakan.Adapun invensi adalah ide inventor yang dituangkan ke dalam suatu kegiatan pemecahan masalah yan spesifik di bidang teknologi, dapat berupa produk atau proses atau penyempurnaan dan pengembangan produk atau proses.

Paten diberikan untuk invensi yang baru dan mengandung langkah insentif serta dapat diterapkan dalam industri. Invensi dianggap baru jika pada tanggal penerimaan invensi tersebut tidak sama dengan teknologi yang diungkapkan sebelumnya.Invensi berupa produk atau alat yang baru dan mempunyai nilai kegunaan praktis disebabkan oleh bentuk, konfigurasi, kontruksi, atau komponennya dapat memperoleh perlindungan hukun dalam bentuk paten sederhana.
\end{abstract}

Kata Kunci : Pengertian Paten Serta Cara Penyelesaian HAKI Mengenai Hak Paten 
A. INTRODUCTION

PENGERTIAN PATEN SERTA

CARA PENYELESAIAN HAKI

MENGENAI HAK PATEN

\section{Pengertian Paten}

Paten adalah hak khusus yang diberikan Negara kepada penemu atas hasil penemuannya di bidang teknologi, untuk lama waktu tertentu melaksanakannya sendiri penemuannya teesebut atau memberikan persetujuannya kepada orang lain untuk melaksanakannya (pasal 1 Ayat 1 UU tentang paten).

Pengertian paten lainnya merupakan hak eksklusif yang diberikan oleh negara kepada inventor atas hasil invensinya di bidang teknologi untuk selama waktu tertentu melaksanakan sendiri invensinya atau memberikan persetujuan kepada pihak lain untuk melaksanakan.Adapun invensi adalah ide inventor yang dituangkan ke dalam suatu kegiatan pemecahan masalah yan spesifik di bidang teknologi, dapat berupa produk atau proses atau penyempurnaan dan pengembangan produk atau proses.

Paten diberikan untuk invensi yang baru dan mengandung langkah insentif serta dapat diterapkan dalam industri. Invensi dianggap baru jika pada tanggal penerimaan invensi tersebut tidak sama dengan teknologi yang diungkapkan sebelumnya.Invensi berupa produk atau alat yang baru dan mempunyai nilai kegunaan praktis disebabkan oleh bentuk, konfigurasi, kontruksi, atau komponennya dapat memperoleh perlindungan hukun dalam bentuk paten sederhana.

Berdasarkan Pasal 8 Undang-Undang Nomor 14 Tahun 2001 tentang Paten, paten diberikan untuk jangka waktu selama 20 tahun, terhitung sejak tanggal penerimaan dan jangka itu tidak dapat diperpanjang. Sedangkan untuk paten sederhana diberikan jangka waktu 10 tahun, terhitung sejak tanggal penerimaan dan jangka waktu tersebut tidak dapat diperpanjang.Paten diberikan berdasarkan permohonan dan setiap permohonan hanya dapat diajukan 
untuk satu invensi atau beberapa invensi yang merupakan satu kesatuan invensi. Dengan demikian, permohonan paten diajukan dengan membayar biaya kepada Direktorat Jendral Hak Paten Departemen Kehakiman dan HAM. Namun, permohonan dapat diubah dari paten menjadi paten sederhana.

Berdasarkan Pasal 66 Undang-Undang Nomor 14 Tahun 2001 tentang Paten, paten dapat dialihkan baik seliruh maupun sebagian karena pewarisan, hibah, wasiat, perjanjian tertulis dan sebab lain yang dibenarkan oleh peraturan perundang-undangan dengan pencatatan oleh derektorat jendral pengalihan paten.

Contoh hak paten : cara mendapatkan hak paten di Indonesia yaitu menganut asas first-to-file, yang artinya siapa saja mendaftarkan invensinya untuk pertama kalinya di kantor Paten akan mendapatkan hak paten. Contoh hak paten : cara mendapatkan hak paten di Amerika Serikat yaitu menganut sisteem first-to-invent, dimana hak paten diberikan kepada seseorang yang pertama kali menemukan.

Hak khusus yang diberikan negara kepada penemu atas hasil penemuannya di bidang teknologi, untuk selama waktu tertentu melaksanakan sendiri penemuannya tersebut atau memberikan persetujuan kepada orang lain untuk melaksanakannya (Pasal 1 UndangUndang Paten). Paten diberikan dalam ruang lingkup bidang teknologi, yaitu ilmu pengetahuan yang diterapkan dalam proses industri. Di samping paten, dikenal pula paten sederhana (utility models) yang hampir sama dengan paten, tetapi memiliki syaratsyarat perlindungan yang 1 bih sederhana. Paten dan paten sederhana di Indonesia diatur dalam UndangUndang Paten (UUP).Paten hanya diberikan negara kepada penemu yang telah menemukan suatu penemuan (baru) di bidang teknologi. 
Cara Penyelesaian Haki Mengenai

Hak Paten

Hukum Yang Mengatur Hak Paten

1. Undang-undang No.14

Tahun 2001 tentang

Paten (UUP);

2. Undang-undang No.7

Tahun 1994 tentang

Agreement Establishing

the Word Trade

Organization

(Persetujuan

Pembentukan Organisasi

Perdagangan Dunia);

3. Keputusan persiden No.

16 Tahun 1997 tentang

Pengesahan Paris

Convention for the

protection of Industrial

Property;

4. Peraturan Pemerintah

No.34 Tahun 1991

tentang Tata Cara

Pemerintah Paten;

5. Peraturan Pemerintah

No. 11 Tahun 1991

tentang Bentuk dan Isi

Surat Paten;

6. Keputusan Menkeh No.

M.01-HC.02.10 Tahun
1991 tentang Paten

Sederhana;

7. Keputusan Menkeh No.

M.02-HC.01.10 Tahun

1991 tentang

Penyelenggaraan

pengumuman paten;

8. Keputusan Menkeh No.

N.04-HC.02.10 Tahun

1991 tentang Persyaratan,

Jangka Waktu, dan Tata

Cara Pembayaran Biaya

Paten;

9. Keputusan Menkeh

No.M.06.- $\quad$ HC.02.10

Tahun 1991 tentang

Pelaksanaan Pengajuan

Permintaan Paten;

10. Keputusan Menkeh No.

M.07-HC.02.10 Tahun

1991 tentang Bentuk dan

Syarat-syarat Permintaan

Pemeriksaan Substantif

Paten;

11. Keputusan Menkeh No.

M.08-HC.02.10 Tahun

1991 tentang Pencatatan

dan Permintaan Salinan

Dokumen Paten; 
12. Keputusan Menkeh No. M.04-PR.07.10 Tahun 1996 tentang Sekretariat Komisi Banding Paten;

13. Keputusan Menkeh No. M.01-HC.02.10 Tahun 1991 tentang Tata Cara Pengajuan Permintaan Banding Paten.

Dasar Hukum HAK PATEN :

1. UU Nomor 6 Tahun 1989 tentang Paten (Lembaran Negara RI Tahun 1989 Nomor 39)

2. UU Nomor 13 Tahun 1997 tentang Perubahan UU Nomor 6 Tahun 1989 tentang Paten (Lembaran Negara RI Tahun 1997 Nomor 30)

3. UU Nomor 14 Tahun 2001 tentang Paten (Lembaran Negara RI Tahun 2001 Nomor 109)

Penyelesaian sengketa hak paten melalui Pengadilan Niaga diatur dalam Pasal 117 Undang - Undang paten yang mana pihak yang berhak atau yang menjadi subjek paten (diatur dalam Pasal 10, Pasal 11, dan Pasal 12) dapat menggugat kepada pengadilan niaga jika suatu paten diberikan kepada pihak lain selain dari yang berhak.

Sebagai Hakim Niaga yang memeriksa sengketa paten harus memahami kasus dan kriteria perlindungannya, yakni :

1. Apakah termasuk objek yang dilindungi.

2. Apakah termasuk kriteria yang dikecualikan dari perlindungan.

3. Apakah memenuhi persyaratan yang dilindungi.

4. Apakah terdaftar di negara tujuan dimana perlindungan diharapkan.

5. Sedangkan penyebab perselisihan dalam sengketa hak paten lazimnya adalah :

1) Ketidak jelasan status kepemilikan.

2) Penggunaan hak paten tanpa seizin pemilik. 
3) Tidak dipenuhinya perjanjian lisensi hak paten.

Dengan sarana Pengadilan Niaga yang dipandang memahami kriteria sengketa paten diharapkan keadilan benar - benar tercapai dan memuaskan. Idealnya setiap putusan Hakim mengandung 3 (tiga) unsur, yaitu :

1. Unsur kepastian hukum.

2. Unsur kemanfaatan.

3. Unsur keadilan.

\section{B. CONCLUSION}

Berdasarkan pembahasan dari bab sebelumnya dapat diambil kesimpulan sebagai berikut :

Pengertian Hak Paten atau definisi hak paten adalah hak ekslusif yang diberikan oleh negara kepada inventor atas hasil invensinya di bidang teknologi, yg untuk selama waktu tertentu melaksanakan sendiri invensinya tersebut atau memberikan persetujuannya kepada pihak lain untuk melaksanakannya.
Pengertian Hak Paten atau definisi hak paten merupakan bentuk perlindungan hak kekayaan intelektual yang sangat efektif karena dapat mencegah pelaksanaan invensi oleh pihak lain tanpa seizin pemegang hak paten, walaupun pihak lain tersebut memperoleh teknologinya secara mandiri (bukan meniru). Menurut UU hak paten No. 14 Tahun 2001 (UU hak paten 2001), hak paten diberikan untuk invensi yang memenuhi syarat kebaruan, mengandung langkah inventif \& dapat diterapkan dalam industri selama 20 tahun.

Dengan sarana Pengadilan Niaga yang dipandang memahami kriteria sengketa paten diharapkan keadilan benar - benar tercapai dan memuaskan. Idealnya setiap putusan Hakim mengandung 3 (tiga) unsur, yaitu :

4. Unsur kepastian hukum.

5. Unsur kemanfaatan.

6. Unsur keadilan.

\section{ACKNOWLEDGEMENT}

University Of Mitra Indonesia 
D. REFERENCE(Based ISO 690 )

A. S. Putra And O. M. Febriani,
"Knowledge Management
Online Application In Pdam
Lampung Province," In
Prosiding International
Conference On Information
Technology And Business
(Icitb), 2018, Pp. 181-187.

[2] A. S. Putra, O. M. Febriani, And B. Bachry, "Implementasi Genetic Fuzzy System Untuk Mengidentifikasi Hasil Curian Kendaraan Bermotor Di Polda Lampung," J. Sist. Inf. Dan Manaj. Basis Data, Vol. 1, No. 1, Pp. 21-30, 2018.

[3] O. M. Febriani And A. S. Putra, "Sistem Informasi Monitoring Inventori Barang Pada Balai Riset Standardisasi Industri Bandar Lampung," J. Inform., Vol. 13, No. 1, Pp. 90-98, 2014.

[4] Putra, Arie Setya. "2018 Artikel Struktur Data, Audit Dan Jaringan Komputer." (2018).

[5] Putra, A. S. (2018, July 17). Paperplain Fundamental Create Application With Borland Delphi 7.0 University Of Mitra Indonesia. Retrieved From Osf.Io/Pbrn9.

\section{E. REFERENCE(Based APA )}

Putra, A. S., Aryanti, D. R., \& Hartati, I. (2018, November). Metode SAW (Simple Additive Weighting) sebagai Sistem Pendukung Keputusan Guru Berprestasi (Studi Kasus: SMK Global Surya). In Prosiding Seminar Nasional Darmajaya (Vol. 1, No. 1, pp. 85-97).

Sari, D. P., Febriani, O. M., \& Putra, A. S. (2018, November). Perancangan Sistem Informasi SDM Berprestasi pada SD Global Surya. In Prosiding Seminar Nasional Darmajaya (Vol. 1, No. 1, pp. 289-294).

Putra, A. S. (2018). Paperplain: Execution Fundamental Create Application With Borland Delphi 7.0 University Of Mitra Indonesia.

Putra, A. S., Sukri, H., \& Zuhri, K. Sistem Monitoring Realtime Jaringan Irigasi Desa (JIDES) Dengan Konsep Jaringan Sensor Nirkabel. IJEIS (Indonesian Journal of Electronics and Instrumentation Systems), 8(2), 221232.

Darmawan, A., Yuliawati, D., Marcella, O., \& Firmandala, R. (2016). Sistem Absensi dan Pelaporan Berbasis Fingerprint dan SMS Gateway. EXPLORE, 7(1).

Febriani, O. M., Wahyuni, T., \& Yusuf, S. (2017). DESIGN OF WEBSITE-BASED INFORMATION SYSTEM FOR EDOCUMENT ADMINISTRASI IN THE COMMUNITY SERVICE UNIT (A Case Study at Rajabasa District). INTERNATIONAL JOURNAL OF 
COMPUTERS \& TECHNOLOGY, 16(7), 7010-7020.

Febriani, O. M., \& Wahyuni, T. (2017, October). PERANCANGAN SISTEM E-DOCUMENT ADMINISTRASI LOGBOOK PENELITIAN PADA UNIT LAYANAN DI BANDAR LAMPUNG. In Prosiding Seminar Nasional Darmajaya (Vol. 1, No. 1, pp. 187-194).

Febriani, O. M., \& Permadi, A. B. (2017). Implementasi Sistem Aplikasi Data Bimbingan dan Pelanggaran Siswa pada Sekolah Menengah Atas di Lampung Tengah dengan Metode Analisis dan Desain Sistem Terdistribusi (SSAD). EXPERT, 7(1).

Febriani, O. M., \& Ambarwati, L. (2015). PERANCANGAN APLIKASI PENGOLAHAN DATA PENJUALAN UKM KELANTING KHAS TELO DESA SIDOHARJO KECAMATAN JATI AGUNG KABUPATEN LAMPUNG SELATAN. Jurnal Teknologi Informasi dan Bisnis Pengabdian Masyarakat Darmajaya, 1(1), 77-95.

Febriani, O. M. (2015). Rancang Bangun Aplikasi Ecommercemenggunakan Freewebstore pada UKM Kelanting di Desa Sidoharjo Lampung Selatan. Prosiding Sembistek 2014, 1(02), 446-458. 